\title{
The Efficacy of Drama in Field Experience: A Qualitatıve Study Using Maxqda
}

\author{
Senel Elaldi ${ }^{1} \&$ Nazli Sila Yerliyurt ${ }^{2}$ \\ ${ }^{1}$ Foreign Languages Department, University of Cumhuriyet, Sivas, Turkey \\ ${ }^{2}$ Education Faculty, Department of Preschool, University of Cumhuriyet, Sivas, Turkey \\ Correspondence: Senel Elaldi, Foreign Languages Department, University of Cumhuriyet, Sivas, Turkey. Tel: \\ 90-346-219-1665. E-mail: snlelaldi@gmail.com
}

Received: July 8, 2016

doi:10.5539/jel.v6n1p10
Accepted: August 31, 2016

Online Published: September 29, 2016

URL: http://dx.doi.org/10.5539/jel.v6n1p10

\begin{abstract}
This study attempted to evaluate the views of senior preservice preschool teachers on the efficacy of drama activities in their field experience in terms of the effect of students' learning, socialization, individual or group work skills and school connectedness and also disclosed the suggestions of senior preservice preschool teachers for faculty members who give drama lectures regarding the delivery of drama course. The study group included $51($ Female $=37$, Male $=14)$ senior preservice preschool teachers studying in the Faculty of Education at Cumhuriyet University, Turkey in the spring semester of the 2016-2017 academic year. Data were collected through an interview form including five semi structured questions that were prepared in line with the aim of the study by the researchers. The data were analyzed using MAXQDA-11, qualitative data analysis software, and descriptive analysis technique. Main themes were generated and then the views were aligned under the themes. The findings revealed that senior preservice preschool teachers had positive views regarding the impact of drama activities in their field experience. In-service training programs were suggested to be designed systematically for professional development of preservice teachers.
\end{abstract}

Keywords: senior preservice preschool teachers, field experience, drama activities, Maxqda-11, descriptive analysis

\section{Introduction}

Teaching through play-based activities with active participation of children is emphasized by researches in the field of preschool education not only as a central strategy to achieve all objectives within the 2006 Turkish Preschool Education Curriculum but also to comply with the European Union and international norms in the field (Gürkan, 2013). However, although play has been framed within preschool education as the best teaching and learning approach, most of preschool teachers are unable to implement teaching through play in their classroom (Cheng \& Stimpson, 2004) for a variety of reasons. For example, many teachers say the curriculum does not incorporate play, there isn't time for it, and many school administrators do not value it (Miller \& Almon, 2009). When Graue (2001) examined why teachers are unable to incorporate their positive beliefs about play in their classrooms, the results indicated that pressure was the main cause stemming from administrators and colleagues, assessment mandates, and parents. Additionally, since many younger preschool teachers did not grow up with a strong experience of child-initiated play due to their free time being filled with electronic media and organized activities, they need to experience play themselves to understand its role in effective education (Miller \& Almon, 2009).

There are five primary types of play in which children engage: loco-motor, social, object, language and dramatic or pretend play (Smith \& Pelligrini, 2013). While each type of play has its own benefits for the developing mind of a young child, dramatic play is becoming an increasingly popular component in toddler and preschool education and defined by experts as a type of play where children assign and accept roles and act them out (Punkoney, 2013). While drama is a powerful learning medium (Andersen, 2004; Braverman, 2002; Taylor \& Warner, 2006) allowing teachers and students to explore anything, anyone, anytime, and anyplace (Friedmann, 2012), dramatic play is the backbone of the drama world, which embraces role-play as a way to gain a deeper understanding of the world (Braverman, 2002). 
Ward (1957; as cited in Hooper Trout, 1978) described dramatic play as "the make-believe of young children", in which they "try on 1 i f e" (p. 137) by putting themselves in the place of grown-ups, animals, and objects. Filled with adventure and discovery, it has no recognizable plot or form. In contrast, drama which often has "a definite beginning, a climax, and a culmination" (p. 138) includes dramatic play, story dramatization, impromptu pantomime, shadow and puppet plays, and other extemporaneous drama forms. According to Hooper Trout (1978), dramatic play, as one of the many types of play in which the child impersonates or identifies with someone or something other than himself, is a prelude to drama and when dramatic play ceases to be an end in itself, the child may move with the help of an adult from dramatic play to drama. In other words, drama is introduced by an adult or someone who influences the form of dramatic play with conventions like setting, character, climax, and developing action. She also acknowledged that the following activities initiate dramatic play and affect children's movement into drama (1) telling original stories; (2) interpreting events and characters from movies, television, and books; and (3) engaging in physical movement.

Although an increasing amount of research supports that dramatic play helps in developing social skills of preschool children and provides children with emotional regulatory skills by giving them opportunities to symbolically create and modify highly arousing emotional events (Kravtstov \& Kravtsova, 2010), there still exists a gap between understanding its value and actually applying it (Furman, 2000).

\subsection{Drama Activities}

Drama activities combine acting and learning at the same time with entertainment and fun (Philips, 2003). Therefore, a classroom with drama activities motivates children to learn and provides them with a relaxing environment in which to study (Sirisrimangkorn \& Suwanthep, 2013). According to Makita (1995), drama activities are valuable classroom techniques that encourage students to participate actively in the learning process. This means, "an involved child is an interested child, an interested child will learn, and drama directly involves the child" (Gomez, 2010, p. 31). Drama involves such activities as role-playing, mime, simulation, and improvisation (Davies, 1990; Gaudart, 1990).

\subsubsection{Role Playing}

Role playing gives children the opportunity to exhibit mimic behaviors and verbal expressions of someone or something they are pretending to be (Cecchini Marie, 2008). Role playing engages children in real-life situations that can be "stressful, unfamiliar, complex, or controversial" which requires them to examine personal feelings toward others and their circumstances (Bonwell \& Eison, 1991, p. 47). While children imitate one or two actions at first, they are able to expand their roles by creating several actions relevant to the role they are playing as time progresses (Cecchini Marie, 2008). Therefore, role play has positive effects on children's communicative and affective skills as it stimulates the children's authentic conversation and allows them to act in a framework, so they can overcome their fear of certain emotional, linguistic or social constraints (Brash \& Warnecke, 2009).

\subsubsection{Mime}

Mime is an effective way of awakening children to the body and nonverbal ways of communication (Dinham, 2011) and defined as acting without words or in other words, "a non-verbal representation of an idea or story through gesture, bodily movement and expression" (Dougill, 1987, p. 13). During the mime, although no language is used, "the mime itself can act as a catalyst to generate and elicit language before, during, and after the activity" (Gaudart, 1990, p. 235). From the point of the teacher, miming may as well be a good method how to integrate even those students whose language abilities are not the best and in most of the activities want to keep back (Hillová, 2008).

\subsubsection{Simulation}

Simulation is an activity in which children discuss a problem (or perhaps a series of related problems) within a defined setting (Davies, 1990) and this activity provides a specific situation within which children can practice various communication skills like asserting oneself, expressing opinions, convincing others, arguing eliciting opinions, group-problem solving, analyzing situations and so on (Smith, 1984). Therefore, simulation exercises can teach children how to function in a social situation with the appropriate social niceties (Davies, 1990).

\subsubsection{Improvisation}

Improvisation is "a play without a script", and therefore, there is no dependency upon reading or memory skills (Davies, 1990, p. 94). Children can be free to act and create the character that they want to be (Wagner, 2002). It requires children to produce appropriate words emotionally by using gestures and facial expressions and to discover their own resources (McCashin, 1990). Improvisational exercises provide three main goals: a child's 
pronunciation improves, proper use of a grammatical structure is reinforced, and vocabulary practice is enhanced (Florea, 2011).

Today there are 72 Faculties of Education, 64 of which are at state universities and 8 are at private universities, within the scope of the Council of Higher Education in Turkey (Eret, 2013). Students are admitted to Faculties of Education through their scores from the nation-wide university entrance exam. Preschool teacher education lasts four years in the Faculties of Education of these universities. When students graduate from Turkish preschool teacher education programs are granted their preschool/kindergarten teaching license, and are entitled to teach in public and private preschools and kindergarten classes (Aldemir \& Kurt, 2014). In the final year of undergraduate education, preservice preschool teachers have practica/field experience as part of teacher training. Practica/field experience helps preservice teachers continue the transformation they experience throughout their program courses and gain crucial professional dispositions to work with young children and their families, teach in preschool classroom, and be an advocate for the profession (Aldemir \& Kurt, 2014). Additionally, during practicum, preservice teachers are given the opportunity to experience and experiment their knowledge and skills in an authentic teaching and learning environment (Kennedy, 1996).

The practicum structure comprises three basics objectives; observation, practica, and student teaching (Manzar Abbas \& Lu, 2013). In order to fulfill these objectives, preservice preschool teachers have field experience in public kindergartens, independent preschools, and private preschools. In the first semester of third year, they visit these practice schools one day a week for observation. On the other hand, the Practice Teaching course, which offers six hours (one day every week) for practicum in practice schools and two hours for education in their departments, is taken by senior preservice preschool teachers in the $7^{\text {th }}$ and $8^{\text {th }}$ semesters of their final years before graduation. Therefore, senior preservice preschool students have opportunities to apply drama based activities in school settings during their field experience.

\subsection{Aim of the Study}

The main purpose of the study is to evaluate the views of preservice preschool teachers on the efficacy of drama in their clinical experience. In line with this aim, the following sub-aims have been included in the study:

1) What are the preservice preschool teachers' views regarding the impact of drama activities on:

(a) learning,

(b) socialization of students,

(c) individual or group work skills, and

(d) school connectedness.

2) What are the preservice preschool teachers' suggestions regarding the delivery of drama course?

\section{Method}

Qualitative research methodology was used to clarify the purpose of the study with a holistic approach. Since the aim of qualitative studies is to provide an accurate description of a real situation, such studies attempt to directly present the opinions of individual participants and to collect data through detailed and in-depth methods (Yıldırım \& Şimşek, 2008). Case study research design was employed to obtain detailed and in-depth information on several cases (Creswell, 2007).

\subsection{Study Group}

The study group included $51($ Female $=37$, Male $=14)$ senior preservice preschool teachers studying in the Faculty of Education at Cumhuriyet University, Turkey in the spring semester of the 2016-2017 academic year. A convenience sampling technique was generated for this study (Patton, 2002) due to being the subjects readily available and being fast, inexpensive, and easy (Dörnyei, 2007).

\subsection{Data Collection}

Data for the study were collected through an interview form including five semi structured questions that were prepared in line with the aim of the study by the researchers. It is important for the reaches to conduct ethical studies and to ensure trustworthiness of their studies (Merriam, 1998). In this regard, for establishing validity of this study, a pilot study was conducted with one female participant. When this pilot participant completed the research questions, she allowed us to make small adjustments to the interview questions. On the other hand, since selecting volunteer students is a key factor to provide validity and reliability of the data collection tool (Yıldırım \& Şimşek, 2008), volunteer students were included in the study. Additionally, in order to ensure the reliability and validity of the qualitative data, direct quotations were given from the typical examples of 
sentences said by the participants. Moreover, interrater reliability, tested by Cohen's kappa statistical measure, was established for examining the agreement between the evaluations of two observers (Cohen, 1960) and was calculated separately for each theme and given in Table 6 (see Appendix). Cohen's kappa coefficient of each theme was aligned as .708 for the impact of drama activities on learning, .769 for the impact of drama activities on socialization of students, .814 for the impact of drama activities on individual or group work skills, .783 for the impact of drama activities on school connectedness and, .775 for suggestions of the participants regarding the delivery of drama course. According to Cohen (1960), weighted Kappa statistics were defined as follows: Kappa $<0$ was considered to indicate no agreement; Kappa $=0.0$ to 0.20 as slight agreement; Kappa $=0.21$ to 0.40 as fair agreement; Kappa $=0.41$ to 0.60 as moderate agreement; Kappa $=0.61$ to 0.80 as substantial agreement; Kappa $=0.81$ to 1.00 as almost perfect agreement .

\subsection{Data Analysis}

Each participant's responses were coded as P1-M/F $/ \mathrm{P}:$ Participant; 1:Participant No; M:Male/F:Female). First, all interview data based on participants' responses to each question were transcribed verbatim. The researchers reviewed the transcripts for accuracy and to generate coding categories and subcategories in line with the aims of the study. In this regard, the data of the study were analyzed using MAXQDA 11, qualitative data analysis software, and descriptive analysis technique. In descriptive analysis, collected data are interpreted by summarizing in view of pre-defined themes (Yıldırım \& Şimşek, 2008). During the analysis process, four-step qualitative data analysis strategies (Tutty, Rothery, \& Grinnell, 1996) were used. First step involved identifying codes "meaning units" from the participants' answers to the questions in the interview form. The codes were arranged by clustering similar ones into a category or theme and separating dissimilar ones to create distinct categories (Karasar, 2012). In the second step, the meaning unit codes were sorted and placed in their emergent categories, and the categories were analyzed for themes or patterns. In step three, the categories were examined for meaning and interpretation. In step four, a diagram was constructed to illustrate the codes and themes found in the data (Miles \& Huberman, 1994) (See Figure 1).

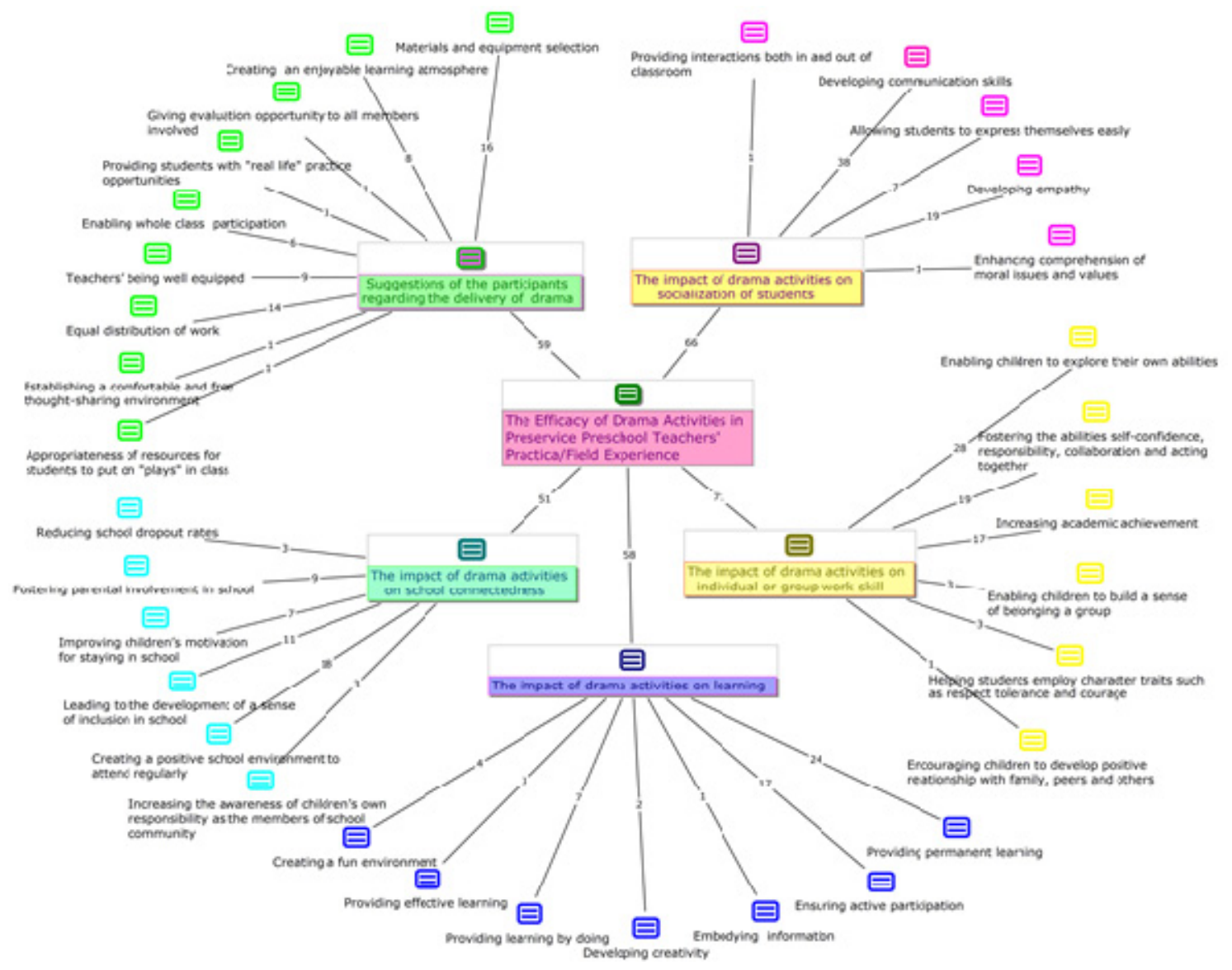

Figure 1. Emerging themes and related codes 


\section{Results}

Regarding the analysis of the answers to the research questions via Maxqda 11, a code list was generated and the codes fell under five themes: (1) The impact of drama activities on learning, (2) The impact of drama activities on socialization of students, (3) The impact of drama activities on individual or group work skills, (4) The impact of drama activities on school connectedness, and (5) Suggestions of the participants regarding the delivery of drama course. These themes and related codes are shown above in Figure 1.

\subsection{The Impact of Drama Activities on Learning}

Views of the participants regarding the first emerging theme that is the impact of drama activities on learning and the related subthemes and their frequencies are given in Table 1.

Table 1. Views of the participants regarding the impact of drama activities on learning

\begin{tabular}{lc}
\hline Views & $\mathbf{f}$ \\
\hline Providing permanent learning & $\mathbf{2 4}$ \\
Ensuring active participation & $\mathbf{1 7}$ \\
Providing learning by doing & $\mathbf{7}$ \\
Creating a fun learning environment & $\mathbf{4}$ \\
Providing effective learning & $\mathbf{3}$ \\
Developing creativity & $\mathbf{2}$ \\
Embodying information & $\mathbf{1}$ \\
Total & $\mathbf{5 8}$ \\
\hline
\end{tabular}

Table 1 shows the views of the participants regarding the impact of drama activities on learning. Throughout the interviews the most frequently reported subtheme was related to the impact of drama activities on providing permanent learning. Although some things that are learned may be forgotten, learning is a permanent process, which can be reinforced by practice or experience (Olson \& Hergenhahn, 2013). In this regard, drama activities in learning patterns help permanence of the acquired knowledge (Umar \& Okka, 2012). Some views of the participants were associated with including drama activities in daily life tasks in order to make all students be actively involved in the lesson. In this vein, a participant (P15/M) stated, "Drama provides permanent learning by associating learning with daily life". Another participant (P2/F) commented, "Drama allows students to make connections with real life and provides meaningful permanent learning". Another participant (P47/M) stated, "Children learn permanently by playing particular aspects of daily life in the drama and they can actively explore situations closely related to their own life experiences by acting in drama".

Another participant (P29/F) emphasized drama as being practical training that enables students to extend their permanent learning and insight, and added, "Since drama includes practical training, it enables students to put into practice skills they have learnt in the fictional context of the classroom and allows them to build their own bridges of understanding permanently". One of the participants (P39/M) stressed, "Drama is a reflection of everyday life to the classroom and appeals to our sense organs, that's why, it enables permanent learning". Participants also reported that drama activities helped students provide learning by doing and ensure active participation so that these activities enabled not only to develop effective learning but also to create a fun learning environment. Since the effectiveness is the most desired result from an instructional program, using drama activities therefore seemed to be an indicator how much students understand subjects when they are engaged and actively involved in the lesson. A participant (P38/M) asserted, "Drama provides opportunities for the students to be involved actively. When the student involves himself in the tasks, by acting someone else and becoming someone else for a short while, he puts forth his whole personality and his mental process and that's why, effective learning can be achieved". For some students (e.g., P5/F, P16/F, and P36/F), it is the best way for students to experience learning by doing that drama enables rather than just reading or listening. Due to the fact that drama is a means of actively participating in learning process to practice and rehearse new skills, it helps students identify their own thinking with other perspectives and awareness of other students' points of view. Furthermore, "when children are actively involved, drama will not only enable them to experience working positively within a group setting, but also to develop good relationships with other group members" (P10/M). On 
the other hand, in terms of creating fun environment, most of the participants shared their views positively. In this vein, a participant (P30/F) stated "Depending on my observations, I can claim that children learn better by integrating classroom curriculum into a game and teaching it in a fun environment". Another participant (P24/F) commented "Children can create physical representations through games... when teachers get them physically involved in the lesson, they will attract children's interest in gaining learning experience". A participant (P45/F) stated, "While children are having more fun, and maybe they are learning more..."

\subsection{The Impact of Drama Activities on Socialization of Students}

The second theme emerging from the views of the participants was related to the impact of drama activities on socialization of students. Related sub-themes and frequencies were given in Table 2.

Table 2. Views of the participants regarding the impact of drama activities on socialization of students

\begin{tabular}{lc}
\hline Views & $\mathbf{f}$ \\
\hline Developing communication skills & $\mathbf{3 8}$ \\
Developing empathy & $\mathbf{1 9}$ \\
Allowing students to express themselves easily through their voices or bodies & $\mathbf{7}$ \\
Enhancing comprehension of moral issues and values & $\mathbf{1}$ \\
Providing interactions both in and out of classroom & $\mathbf{1}$ \\
Total & $\mathbf{6 6}$ \\
\hline
\end{tabular}

Table 2 shows that almost all the participants agree on the idea that drama has a positive effect on socialization of children. For some participants (e.g., P45/M, P1/F, P48/M and P34/F), drama fosters the ability of speaking in front of others, and therefore, it makes children more open to be able to express their feelings to say what they are thinking and not just keep them buried down inside. For them, interacting with others promotes speaking and listening skills. On the other hand, some participants (P17/F and P19/F) stressed that due to being a lot more communication happening around them, children make some lasting friendships much easier in a drama activity based class than they would in other classes. The participant P17/F also stressed the relationship between drama activities and empathy as "When children take on several roles in drama, they use all their senses to understand the characters they portray and therefore, they not only will learn how to express oneself in a character but also are better able to show empathy for others".

When children take part in a drama play, they realize that they must listen to what other players say in order to be able to respond them. They also realize that they must choose their words appropriately so that others can understand exactly what they mean when they are trying to communicate. A participant (P23/F) expressed, "Children explore and establish moral values such as integrity, justice and compassion that may be different than their own and they engage in reflecting upon their own moral values through drama oriented activities". Other participant (P29/F) added, "Drama activities particularly provide opportunities for creating an interactive environment both in and out of classroom and they are powerful in building up communicative competence of children".

\subsection{The Impact of Drama Activities on Individual or Group Work Skills}

The views of the participants regarding the impact of drama activities on individual or group work skills are given in Table 3. 
Table 3. Views of the participants regarding the impact of drama activities on individual or group work skills

\begin{tabular}{lr}
\hline Views & $\mathbf{f}$ \\
\hline Enabling children to explore their own abilities & $\mathbf{2 8}$ \\
Fostering the abilities of self-confidence, responsibility, collaboration and acting together & $\mathbf{1 9}$ \\
Increasing academic achievement & $\mathbf{1 7}$ \\
Helping students employ character traits such as respect, tolerance, kindness, and courage & $\mathbf{3}$ \\
Enabling children to build a sense of belonging to a group & $\mathbf{3}$ \\
Encouraging children to develop positive relationships with family, peers and others & $\mathbf{1}$ \\
Total & $\mathbf{7 1}$ \\
\hline
\end{tabular}

As given in Table 3, the participants' views support that drama activities have positive effects on the development of individual or group work skills. Since drama based activities enable students to function in terms of promoting group working skills and building personal relationships (Sirisrimangkorn \& Suwanthep, 2013), students' individual participation or group cooperation in drama enhance their interaction and build positive social relationships. In this vein, some participants (e.g., P25/F, P27/F, P30/F, and P35/M) stated that drama activities help children develop an understanding of other people, in particular, what to expect from others in different situations. Moreover, due to the fact that drama leads or forces students to use their own and express their true feelings or sense of personality without fear of being judged or criticized, children get things off their mind and behave who they are. Another participant (P15/M) remarked that drama activities have positive effects on academic achievement and performance. Related to the impact of drama activities on academic achievement, one participant (P36/F) stated, "Drama activities engage children in planning and decision making and therefore, they improve achievement". Another participant (P38/M) pointed out "Drama activities can improve skills and academic performance of the students who participate in drama due to their being more engaged in lessons than their nonparticipant counterparts". In terms of other positive outcomes, most of the participants shared prevalent feelings encompassing biological or social development with the help of drama activities. In this regard, one participant $(\mathrm{P} 1 / \mathrm{F})$ stated "Since inclusion of an individual in a group is a sign of belonging, a sense of belonging to a group is a positive social outcome of drama experience". According to a participant (P48/M), "Drama activities foster collaborating in a positive way". Other participant (P34/F) also added "Drama encourages children to work with others in a collaborative way". For some participants (e.g., P27/F, P12/F, and P17/F), exposure to drama experience will lead to an improvement in relationships with family, peers and others and help children learn to engage in deepening their perspectives. For them, drama can provide a context to help children learn to respect others, to behave appropriately and create positive outcomes such as respect, empathy, flexibility, tolerance, kindness, openness, and courage. Another point stressed by the participants is that the relationship between drama and boosting children's confidence. For example, one participant (P9/F) stated "The sense of expressing their own feelings boosts children's confidence". Another participant (P2/F) added "Giving a presentation in front of a class will boost children's confidence". Furthermore, some participants (e.g., P10/M and P3/F) stressed that drama makes students more open so they are able to say things calmly without screaming because drama helps them control the biology of their body like hate or anger. According to P3/F, "with the help of drama activities, shy students can break out of their shells and develop self-confidence". In terms of taking responsibility, a participant (P51/F) stated "Drama activities encourage them to take risks and sharing responsibilities. Children know that when they are in a drama activity, there is a pressure on them to be responsible and so, without skipping, they come to drama course because they have already learned that they have a responsibility to the group and if they are not there, the group cannot function. So, they learn the responsibility and counting on the group members". Another participant (P49/F) remarked "Drama activities provide opportunities for children to take responsibility for their own learning".

\subsection{The Impact of Drama Activities on School Connectedness}

Another theme emerging from the views of the participants was related to the impact of drama activities on school connectedness. The related sub-themes and frequencies are given in Table 4. 
Table 4. Views of the participants regarding the impact of drama activities on school connectedness

\begin{tabular}{lr}
\hline Views & $\mathbf{f}$ \\
\hline Creating a positive school environment to attend regularly & $\mathbf{1 8}$ \\
Leading to the development of a sense of inclusion in school & $\mathbf{1 1}$ \\
Fostering parental involvement in school & $\mathbf{9}$ \\
Improving children's motivation for staying in school & $\mathbf{7}$ \\
Reducing school dropout rates & $\mathbf{3}$ \\
Increasing the awareness of children's own responsibility as the members of school community & $\mathbf{3}$ \\
Total & $\mathbf{5 1}$ \\
\hline
\end{tabular}

Table 4 represents the views of the participants regarding the impact of drama activities on school connectedness. Many participants emphasized that drama activities enhance school connectedness through providing positive school environment that include teacher support, positive peer relations, safety, belonging and feeling a part of school. In this regard, one participant (P48/F) stated "Drama activities make children feel valued among their friends and teachers at school". Another participant (P10/M) stated "Children feel like that they are a part of their school". One participant (P30/F) reported "Children feel safe and close to peers and teachers at their school when taking part in a drama performance". According to the participant P17/F, "A child feels that his/her teachers care about him/her too much due to being a performer of drama and therefore, drama activities make children happy to be at their school". The participant P8/F stated "When children are involved in drama activities, they are happier at school than when they are not at school". In this regard, another participant (P46/M) stated "Active participation in drama activities makes children feel connected to school that they belong and therefore, they look forward to going to school every day". In addition, according to the participant P3/F, "Drama helps improve school attendance and reduce school dropout rates and, as a result, children are more likely to succeed academically when they feel connected to school".

Related to family involvement, a participant (P1/F) stated "I think drama activities make parents to be really interested in what is happening at school because they hear about it so much and they see how much their children are excited about school". Another participant (P43/F) added "Drama activities create opportunities to strengthen parents' involvement in student achievement, as well as share their expectations".

\subsection{Suggestions of the Participants Regarding the Delivery of Drama Course}

The participants shared their suggestions for the teachers who deliver drama courses. The emerging subthemes related to these suggestions and frequencies are given in Table 5.

Table 5. Suggestions of the participants regarding the delivery of drama course

\begin{tabular}{lr}
\hline Views & $\mathbf{f}$ \\
\hline Materials and equipment selection & $\mathbf{1 6}$ \\
Enabling equal distribution of work & $\mathbf{1 4}$ \\
Teachers' being well equipped & $\mathbf{9}$ \\
Creating an enjoyable learning atmosphere & $\mathbf{8}$ \\
Enabling whole class participation & $\mathbf{6}$ \\
Providing students with "real life" practice opportunities & $\mathbf{3}$ \\
Establishing a comfortable and free thought-sharing environment & $\mathbf{1}$ \\
Giving evaluation opportunity to all members involved & $\mathbf{1}$ \\
Appropriateness of resources for students to put on "plays" in class & $\mathbf{1}$ \\
Total & $\mathbf{5 9}$ \\
\hline
\end{tabular}


As shown in Table 5, most of the participants' suggestions were related to carefully selection of supportive materials and course equipment so as to enrich the students' experience in daily life. In this sense, a participant (P11/F) stated "materials selected for the dramatic play area should support the development of children's ability and foster success". Another participant (P32/F) commented "Providing appropriate equipment and materials that fit the capabilities of students help them enrich their learning experiences". According to the participant P17/F, "Materials should be concrete and relevant to students' own life experiences and safe for them, as well". Participants also made suggestions that teachers should give all students the opportunity to gain experience by enabling equal distribution of work. For example, a participant (P30/F) suggested that "Teachers should distribute work among students depending upon their abilities and making sure that there is equal distribution". They gave importance to teachers' being well equipped as well. One participant (P2/F) stated that "In order to help students' learning through doing and experiencing, they need more practical knowledge. Therefore, they should be well equipped to teach drama courses". Another point that some participants addressed was related to making learning an enjoyable experience by creating an enjoyable atmosphere. For example a participant (P25/F) suggested that "Teachers should transmit enthusiasm to students to make learning an enjoyable experience". Creative fun activities were certainly seen to be important for students to be engaged in the lesson. One participant (P20/F) stated "being fun and entertaining of drama motivates students to focus on the topic". According to the participant P23/F, "Teachers should be well-poised and relaxed in order to create an enthusiastic atmosphere in a drama lesson". Another participant (P9/F) suggested that all students should be engaged in the lesson and added, "The best way to get everyone involved, even the shyest students, is using a drama activity with a large class". On the other hand, some suggestions were for the evaluation of drama activities that should be carried out by taking feedback from students (P46/M) and by all members involved $(\mathrm{P} 48 / \mathrm{M})$. For the last subtheme that is appropriateness of resources for students to put on "plays" in class, only one participant (P9/F) suggested that "Drama resources should be appropriate for students to put on 'plays' in class. Otherwise, it can be fruitless and time consuming".

\section{Discussion}

This study aimed to evaluate the views of senior preservice preschool teachers $(n=51)$ studying in the Faculty of Education at Cumhuriyet University, Turkey on the efficacy of drama education in their clinical experience. The participants displayed positive and agreeable attitudes toward the impact of drama activities on learning, socialization of students, individual or group work skills, and school connectedness. They also made suggestions for faculty members who give drama lectures regarding the delivery of drama course. In line with the positive impact of drama on learning, many studies have yielded similar results (i.e., Aykaç, 2008; Edmiston, 2008; Duban \& Düzgün, 2013; Güllü, 2009; Rosler, 2008; Sawyer, 2004; Selmanoğlu, 2009; Yamamoto, 2015; Y1lmaz, 2006). In this vein, drama can be considered not only as an effective pedagogical method to increase achievement scores of students alongside other instructional methods (Lee, Patall, Cawthon, \& Steingut, 2014), but also as a teaching method to make students cognitively physically active in teaching and learning process in today's classrooms (Courtney, 1989). According to the views of the participants related to the impact of drama on learning, drama activities provide permanent learning, active participation, learning by doing, effective learning, fun learning and development of creativity that were all supported in previous research results (Bertiz, 2005; Duban \& Düzgün, 2013; Durusoy, 2012; Morris, 2001; Özdemir \& Çakmak, 2008; Umar \& Okka, 2012). Some views of the participants reflected that children learn by playing particular aspects of daily life and explore situations closely related to their own life experiences. In this vein, Masoum, Rostamy-Malkhalifeh and Kalantarnia (2013), who have claimed that students may learn from what they are doing in drama, supported these views of the participants. In addition, the views of the participants also clarify that the reflection of past experience in learning process through drama encourages students to develop new skills and effective learning (Lewis \& Williams, 1994). In this context, Taylor (1998) stressed that looking back on the students' experience was essential to identify the ways in which students were able to engage with a dramatic encounter, as well as learn about the content to provide permanent learning. On the other hand, most of the participants have asserted that active participation in drama helps students learn permanently and effectively. In this regard, Özdemir and Çakmak (2008) expressed drama to provide active participation rather than being passive, being independent rather than dependency and making independent decisions, becoming democratic, and noticing one's own skills.

Furthermore, the participants of this study shared their views on drama activities that create fun environment in learning. Similarly, the participants in Yamamoto's (2015) study described "fun" as the predominant factor in drama and related education. Whether they described fun as "acting goofy" or "addicted to laughing" or simply "playing", all the participants joined the group in search of fun (p. 125). Additionally, Ting (2005) found that children enjoyed learning language through drama activities due to their combining action and entertainment for 
students. In this regard, Guida (1995) found with drama, even some students who don't have confidence to speak up in public are willing to join in the drama activities. They have a lot of fun and become creative, and often able to speak naturally. According to Gaudart (1990), students don't only have fun but also learn a variety of components from acting the story. He also claimed that although drama activities can bring a lot of fun for students, at the end of class, some parents may complain that their children learned nothing from the drama activity. Another point that the participants of this study mentioned was that drama activities allow children to develop abstract thinking skills. Similarly, Rosler's (2008) study of using drama in a fifth grade social studies class indicated that although students did not explore whether understanding of concepts, abstract concepts, or responses to abstract questions, students who participated in drama demonstrated the ability to make links between different texts. Participating in drama helped them better understand the expository textual material in the textbook. In a similar vein, Heller (2005), who studied how drama in education techniques supported the development of abstract thinking in fifth graders, has demonstrated that abstract thinking can occur within drama and drama can support children's understanding of an abstract concept.

For the impact of drama activities on socialization of students, this study revealed that almost all the participants agreed that drama had a positive effect on socialization of children. In the literature review, certain studies discussed similar results (Bayrakçı, 2007; Bergen, 2002; Gillen, 2000; Nichols \& Stitch, 2000; O’Neill, 2008; Pass, 2007; Rasmussen \& Gürgens, 2006; Staples, 2007; Şimşek, 2013; Yamamoto, 2015). When Gardner (1985) described the unique social qualities of drama, he mentioned that "interacting with others gives a very special flavor to the drama" (p. 309). Additionally, social integration fosters pupils' critical thinking, problem solving, improves oral communication skills (Aldavero, 2008) and helps them become more outgoing, productive, and determined individuals (Şimşek, 2013). On the other hand, through social interaction in drama, shy students gain more confidence and abandon their embarrassment and shyness (Phillips, 2003).

According to the views of the participants, drama activities have positive effects on the development of individual or group work skills. According to Gunderson and Moore (2008), drama and role playing through group works enable students to be central of instruction and lead them to construct their own knowledge through multi-dimensional perspectives within active learning environment. At the same time, it enables the child to negotiate rules and agree on the direction of play with a social partner (Lindsey \& Colwell, 2013). Additionally, working in groups generally gives students social skills such as being a member of a group, communicating with others (Morris, 2001) and sharing responsibilities (Tahta, 1999). Medina (2006) found that the drama work, "Provided a powerful context to explore aspects of the students' social realities that could be related to critical literacies" (p. 66) by allowing the students to use their lived experience in the classroom and connecting it to the curricula. Similarly, Kelly (2006), who wanted to reveal what impact the groupings would have on the students' experience in drama, indicated that working with group helped students because they knew these people and they knew they could. On the other hand, the participants of this study agreed that drama activities lead to positive outcomes such as empathy, self-confidence, independent thinking and tolerance. Sawyer (2004) also argued that classroom drama strategies help students' social skills development such as empathy and adaptability that they need in the real world. On the other hand, Goldstein and Winner (2012), who performed a quasi-experimental study to determine whether developmental differences in empathy exist and, if so, how much for students who participate in acting training, found a positive correlation existed between acting training and the students' development of empathy. Treff (2008), who investigated graduate students' perceptions of participation training, found that the students learned through dramatically activities and role-playing and noted that the participants reported increased confidence and self-reflective ability. Similarly, the participants in Burnard's (2002) study described creativity that occurred during drama and an increase in confidence in their ability to interact and perform. Edmiston (2008) found that although the subject group was a seventh grade class, students were able to take on multiple points of view independently by participating in drama. In addition, in Lähdesmäki's (2016) study, in the grouping process, the participants reached the level where they had the feeling of safety to throw themselves into drama together and they got the experience of the multi-level communication between people, fearlessness to be themselves and to throw themselves into a role because they did not need to be afraid of being embarrassed.

The views regarding the impact of drama activities on school connectedness disclosed these activities to yield positive school environment for students so that they provide not only teacher and peer support at school but also parent involvement in school life. Drama activities were also stressed by the participants to reduce dropout rates of students. Some consistency with these results has seen in the related literature. For example, school connectedness is related to teacher support, safety, belonging, fair discipline practices, feeling a part of school and whether the student liked school (Resnick et al., 1997, as cited in Libbey, 2004). Similarly, King, Vidourek, 
Davis and McClellan (2002) remarked that extracurricular activities such as drama, sports, music, and chess enhance children's' understanding of others, acknowledge students' personal achievements, and strengthen their feelings of self-worth. Lohmeier and Lee (2011) stated that a student's sense of school connectedness is based on a collection of values and behaviors related to a student's belongingness, relatedness, and connectedness in association with their school, teachers/adults, and peers. Students are, therefore, more likely to succeed when they feel connected to school (Blum, 2005). Thomas and Smith (2004) confirmed that school connectedness is an important and modifiable factor associated with students' learning and development. While students who participate in extracurricular activities receive higher grades and do not skip school and feel more attached to school (McNeely, Nonnemaker, \& Blum, 2002), students who feel socially isolated may be more sensitive to the negative effects of school connectedness. In this regard, Whitlock (2006) pointed out the components of school connectedness as creative engagement (students are able to participate in activities and subjects of interest to them and to display their talents), and academic engagement (students are able to perform and achieve in academic work). Due to being student engagement tied to improvements in not only student behavior but also learning outcomes (Howe \& Covell, 2007), high levels of student engagement can predict lower high school dropout rates as well (Archambault, Janosza, Fallu, \& Pagania, 2008). Therefore, lack of student engagement is also a remarkable challenge for teachers to bring more voices of encouragement and empowerment into the classroom to increase student achievement and decrease dropout rates. On the other hand, parent involvement plays a major role in improving children's learning. Children whose parents are involved in their learning do better at school, both academically and behaviorally (Patrikakaou, 2008). Research by Thompson et al. (2006) reported similar findings in which connectedness was found to be greater among students, students from a two-parent household, students who performed well in school, those who were active in extracurricular activities, those who had a large number of friends, and those with positive parental involvement in their school.

The participants also made suggestions for teachers who give drama lectures regarding the delivery of drama course. They suggested the selection of appropriate materials and equipment so as to enrich the students' learning and experience. Similarly Hendrix, Eick and Shannon (2012) found that learning outcomes have supported the use of drama as an effective strategy when appropriately implemented and integrated with appropriate materials. On the other hand, in Duban and Düzgün's (2013) study, most of the participants reported that the material in science and technology course made learning much easier if it was given through drama. Another suggestion made the participants of this study was regarding the equal engagement of students in drama activities to gain experience. Similarly, when responding about student engagement for drama based courses, the participant teachers in Cawthon, Dawson, and Ihorn's (2011) study remarked a greater variety of indicators, including positive social interaction (e.g., helping peers, complimenting or encouraging other students, working together to solve problems), physical movements, completion of final products, a wide variety of verbal interaction, and even the positive mood of the students (e.g., smiling and laughing). However, when responding to the student engagement for their original lessons, the same participants gave vague responses such as, "I know students are engaged if they are paying attention", or "I know students are engaged if they are listening". Furthermore, enabling the engagement of whole class in a drama activity was suggested by the participants of this study, as well. Some were recommended all the students, even the shyest ones, be engaged in the lesson through using drama activities. Similar outcomes were observed in Athiemoolam's (2013) study. The participants of which indicated that they were impressed by some of their very shy and withdrawn peers who became more confident and seemed to blossom after their active participation in the dramatic performance. A number of them also indicated that they were initially reluctant to participate in the dramatic presentations, as they had never acted in plays before. However, in reflecting on their experiences, it emerged that their participation in the plays gave them the confidence and served as a vehicle for the discovery of their hidden talents that they never thought they had.

\section{Conclusion}

This study attempted to evaluate the views of senior preservice preschool teachers on the efficacy of drama education in their clinical experience in terms of the effect of students' learning, socialization, individual or group work skills and school connectedness. This study also disclosed the suggestions of senior preservice preschool teachers for faculty members who give drama lectures regarding the delivery of drama course. The data were analyzed using Maxqda 11, qualitative data analysis software, and descriptive analysis technique. The overall results indicated that senior preservice preschool teachers had positive views regarding the impact of drama activities in their field experience. However, the generalizability of these findings is limited, due to the fact that the results were obtained from a relatively small sample of participants from one city in Turkey. Therefore, studies within different methodological approaches encompassing both qualitative and quantitative 
methods in a large sample size through reaching out and keeping in touch with other universities are suggested. It is also suggested that drama classes should be compulsory not only in each department of education faculties but also in all teacher education programs and even, in-service teacher training programs so that drama helps individuals construct knowledge in their minds through meaningful learning activities and gain experience in a learning environment where they can express themselves freely. An obvious point is that this study can only be generalized in the context the study was conducted, but nevertheless, it can have important implications for the impact of drama in preservice preschool teachers' field experience both in Turkey and in other countries.

\section{References}

Aldavero, V. A. (2008). Drama in the development of oral spontaneous communication. Encuentro, 17, 40-43.

Aldemir, J., \& Kurt, G. (2014). A program review: Turkish early childhood education pre-service teachers' perceptions about teacher and teaching. SAGE Open, 4, 1-11. http://dx.doi.org/10.1177/2158244014548847

Andersen, C. (2004). Learning in "as-if" worlds: Cognition in drama in education. Theory into Practice, 43(4), 281-286. http://dx.doi.org/10.1207/s15430421tip4304_6

Archambault, I., Janosza, M., Fallu, J., \& Pagania, L. S. (2008). Student engagement and its relationship with early high school dropout. Journal of Adolescence, 32, 651-670. http://dx.doi.org/10.1016/j.adolescence.2008.06.007

Athiemoolam, L. (2013). Using drama-in-education to facilitate active participation and the enhancement of oral communication skills among first year pre-service teachers. Scenario, 2, 48-62.

Aykaç, M. (2008). Sosyal bilgiler dersinde yaratıcı dramanın yöntem olarak kullanılmasının ögrenci başarısına etkisi [The effect of using creative drama as a method in social sciences class on students' achievement] (Published Master's thesis). Ankara University, Ankara, Turkey.

Bayrakçı, M. (2007). Okulöncesinde yaratıcı drama etkinliklerinin iletişim becerilerinin gelişsmesi üzerindeki etkisi [The effection of creative drama on the sucsess of pre-scholl students comunicating abilities] (Unpublished Master's thesis). Kafkas University, Kars, Turkey.

Bergen, D. (2002). The role of pretend play in children's cognitive development. Early Childhood: Research and Practice, 4, 1-13

Bertiz, H. (2005). Fen Bilgisi öğretmen adaylarının yaratıcı dramaya yönelik tutumları ve öyküleme çallşmalarına ilişskin görüşleri [The attitudes of prospective science teachers' towards creative drama and their views about story work] (Unpublished Master's thesis). Gazi University, Ankara, Turkey.

Blum, R. W. (2005). A case for school connectedness. Educational Leadership, 62(7), 16-20.

Bolton, G. (1985). Changes in thinking about drama in education. Theory into Practice, 24(3), 151-157. http://dx.doi.org/10.1080/00405848509543166

Bonwell, C. C., \& Eison, J. A. (1991). Active learning: Creating excitement in the classroom. Washington, DC: The George Washington University.

Brash, B., \& Warnecke, S. (2009). Shedding the ego: Drama-based role-play and identity in distance language tuition. Language Learning Journal, 37(1), 99-109. http://dx.doi.org/10.1080/09571730902717661

Braverman, D. (2002). Playing a part: Drama and citizenship. UK: Trentham Books.

Burnard, P. (2002). Learning human skills: An experimental and reflective guide for nurses and health care professionals (4th ed.). Oxford, UK: Butterworth-Heinemann.

Cawthon, S., Dawson, K., \& Ihorn, S. (2011). Activating student engagement through drama-based instruction. Journal for Learning through the Arts, 7(1), 1-28.

Cecchini, M. E. (2008). How dramatic play can enhance learning. Early Childhood News. Retrieved from http://www.earlychildhoodnews.com/earlychildhood/article_view.aspx?ArticleID=751

Cheng, P. W. D., \& Stimpson, P. (2004). Articulating contrasts in preschool teachers' implicit knowledge on play-based learning. International Journal of Educational Research, 41(4-5), 339-352. http://dx.doi.org/10.1016/j.jjer.2005.08.005

Cohen, J. (1960). A coefficient of agreement for nominal scales. Educational and Psychological Measurement, 20, 37-46. http://dx.doi.org/10.1177/001316446002000104 
Courtney, R. (1989). Play, drama and thought: The intellectual background to dramatic education (4th ed.). Toronto: Simon \& Pierre.

Creswell, J. W. (2007). Qualitative inquiry \& research design (2nd ed.). Thousand Oaks, CA: Sage.

Davies, P. (1990). The use of drama in English Language Teaching. TESL Canada Journal/Revue Tesl Du Canada, 8(1), 87-99. http://dx.doi.org/10.18806/tesl.v8i1.581

Dougill, J. (1987). Drama activities for language learning. London: Macmillan.

Dörnyei, Z. (2007). Research methods in applied linguistics. New York: Oxford University Press.

Duban, N. Y., \& Düzgün, M. E. (2013). Views of teachers on the use of drama method in science and technology courses. Online Submission, 4(2), 46-55.

Durusoy, H. (2012). 6. sinıf "Kuvvet ve Hareket" ünitesinde basamaklı ögretim yöntemi ve yaratıcı drama yönteminin ögrenci erişisine ve kalıclliğa etkisi [The effects of curriculum layered and creative drama methods on 6th grade "force and movement" unit on student achievement and retention of knowledge] (Master's thesis). Hacettepe University, Ankara, Turkey.

Edmiston, B. (2008). Forming ethical identities in childhood play. Abingdon, Oxon: Routledge.

Eret, E. (2013). An assessment of preservice teacher education in terms of preparing teacher candidates for teaching (Doctoral Dissertation). Middle East Technical University, Turkey.

Florea, P. J. (2011). Using improvisational exercises for increasing speaking and listening skills. Asian EFL Journal, 52, 46-58.

Friedmann, D. (2012). Acting up: Five elementary teachers explore classroom management through dramatic play (PhD Dissertation). New York University.

Furman, L. (2000). In support of drama in early childhood education, again. Early Childhood Education Journal, 27(3), 173-178. http://dx.doi.org/10.1007/BF02694231

Gardner, H. (1985). Towards a theory of dramatic intelligence. In J. Kase-Polsini (Ed.), Creative drama in a developmental context (pp. 295-312). New York: University Press of America

Gaudart, H. (1990). Using drama techniques in language teaching. Available from ERIC database (ED366197).

Gillen, J. (2000). Versions of Vygotsky. British Journal of Educational Studies, 48, 183-198. http://dx.doi.org/10.1111/1467-8527.t01-1-00141

Goldstein, T. R., \& Winner, E. (2012). Enhancing empathy and theory of mind. Journal of Cognition and Development, 13, 19-37. http://dx.doi.org/10.1080/15248372.2011.573514

Gomez, I. D. (2010). Using drama to improve oral skills in the ESL classroom. International School Journal, 30, 29-37.

Graue, M. E. (2001). What's going on in the children's garden? Kindergarten today. Research in review. Young Children, 56, 67-73.

Guida, M. (1995). Creating theater in the ESL classroom. The Journal of the Imagination in Language Learning, 3. Retrieved from http://www.njcu.edu/cill/vol3/ratliff.html

Gunderson, D. E., \& Moore, J. D. (2008). Group learning pedagogy and group selection. International Journal of Construction Education and Research, 4(1), 34-45. http://dx.doi.org/10.1080/15578770801943893

Güllü, M. (2009). Dramatizasyon yönteminin yabancı dil öğretimi üzerindeki etkisi [The effects of dramatization in foreign language teaching] (Unpublished Master's thesis). Beykent University, Ankara.

Gürkan, T. (2013). Okul öncesi eğitim programı. In R. Zembat (Ed.), Okul öncesinde özel ögretim yöntemleri. Ankara: Anı yayıcılık.

Heller, W. (2005). Teaching Shakespeare in the inner-city Fifth-grade classroom using drama-in-education, theatrical production, and technology integration: An action research-based case study (Doctoral dissertation). New York University, New York.

Hendrix, R., Eick, C., \& Shannon, D. (2012). The integration of creative drama in an inquiry-based elementary program: The effect on student attitude and conceptual learning. Journal of Science Teacher Education, 23(7), 823-846. http://dx.doi.org/10.1007/s10972-012-9292-1 
Hillová, A. (2008). The use of drama techniques when teaching a foreign language (Bachelor thesis). Masaryk University, Brno, Czech Republic. Retrieved from http://is.muni.cz/th/170986/pedf_b/thesis.pdf

Hooper Trout, L. (1978). Drama in the elementary classroom: A teacher's discovery of dramatic play (Doctoral Dissertation). Northwestern University. Available on Proquest Dissertations and Theses database.

Howe, R. B., \& Covell, K. (2007). Empowering children: Children's rights education as a pathway to citizenship. Toronto: University of Toronto Press.

Karasar, N. (2012). Bilimsel araştırma yöntemi. Ankara, Nobel Yayın Dağıtım.

Kelly, K. S. (2006). "I'm a lot like her": Entering the world of others through process drama. In J. Jasinski Schneider, T. Crumpler, \& T. Rogers (Eds.), Process drama and multiple literacies: Addressing social, cultural, and ethical issues (pp. 71-88). Portsmouth, NH: Heinemann.

Kennedy, J. (1996). Meeting the needs of teacher trainees on teaching practice. In T. Hedge, \& N. Whitney (Eds.), Power, Pedagogy and Practice (pp. 171-181). Oxford: Oxford University Press.

King, K. A., Vidourek, R. A., Davis, B., \& McClellan, W. (2002). Increasing self-esteem and school connectedness through a multidimensional mentoring program. Journal of School Health, 72(7), 294-299. http://dx.doi.org/10.1111/j.1746-1561.2002.tb01336.x

Kravtsov, G. G., \& Kravtsova, E. E. (2010). Play in L.S. Vygotsky's non-classical psychology. Journal of Russian and East European Psychology, 48(4), 25-41. http://dx.doi.org/10.2753/RPO1061-0405480403

Lähdesmäki, S. (2016). If this is so fun for adults, it must be a thousand times more fun for children!: Adult teacher students experiences on grouping through drama course practices. In INTED 2016 Proceedings: 10th International Technology, Education and Development Conference (pp. 736-743). IATED.

Lee, B. K., Patall, E. A., Cawthon, S. W., \& Steingut, R. R. (2014). The effect of drama-based pedagogy on PreK-16 outcomes: A meta-analysis of research from 1985 to 2012. Review of Educational Research, 20(10), 1-47. http://dx.doi.org/10.1590/S0102-46982014000300001

Lewis, L. H., \& Williams, C. J. (1994). Experiential learning: Past and present. New Directions for Adult and Continuing Education, 62, 5-16. http://dx.doi.org/10.1002/ace.36719946203

Libbey, H. P. (2004). Measuring student relationships to school: Attachment, bonding, connectedness, and $\begin{array}{lllll}\text { engagement. Journal } & \text { 274-283. }\end{array}$ http://dx.doi.org/10.1111/j.1746-1561.2004.tb08284.x

Lohmeier, J. H., \& Lee, S. W. (2011). A school connectedness scale for use with adolescents. Educational Research and Evaluation, 17(2), 85-95. http://dx.doi.org/10.1080/13803611.2011.597108

Makita, Y. (1995). The effectiveness of dramatic/role-playing activities in the Japanese language classroom. Retrieved from http://journals2.iranscience.net:800/meel.pacificu.edu/meel.pacificu.edu/paper s/scholars/makita/makita.htm

Maley, A., \& Duff, A. (2001). Drama techniques in language learning: A resource book for communication activities for language teachers. Cambridge: Cambridge University Press.

Manzar Abbas, S., \& Lu, L. (2013). Keeping the practicum of Chinese preservice teacher education in world's perspective. International Journal of Academic Research in Business and Social Sciences, 3(4), 172-186.

Mariano, C. (2000). Case study: The method. Chapter 10. In P. Munhall, \& C. Oiler Boyd (Eds.), Nursing Research: A Qualitative perspective (2nd ed., pp. 311-337). Sudbury, MA: Jones and Bartlett Publishers.

Masoum, E., Rostamy-Malkhalifeh, M., \& Kalantarnia, Z. (2013). A study on the role of drama in learning mathematics. Mathematics Education Trends and Research, 1-7. http://dx.doi.org/10.5899/2013/metr-00016

McCaslin, N. (1990). Creative Drama in the classroom (5th ed.). Studio City Player Press Inc.

McNeely, C. A., Nonnemaker, J. M., \& Blum, R. W. (2002). Promoting school connectedness: Evidence from the National Longitudinal Study of Adolescent Health. Journal of School Health, 72(4). http://dx.doi.org/10.1111/j.1746-1561.2002.tb06533.x

Medina, C. L. (2006). Identity and imagination of immigrant children: Creating common place locations in literary interpretation. In J. J. Schneider, T. P. Crumpler, \& T. Rogers (Eds.), Process drama and multiple literacies: Addressing social cultural and ethical issues (pp. 53-69). Portsmouth, NH: Heinemann. 
Merriam, S. B. (1998). Qualitative research and case study applications in education. San Francisco: Jossey-Bass.

Miles, M. B., \& Huberman, M. (1994). Qualitative data analysis: A sourcebook of new methods. Beverly Hills, CA: Sage Publications.

Miller, H., Rynders, J., \& Schleien, S. (1993). Drama: A medium to enhance social interaction between students with and without mental retardation. Mental Retardation (now called Intellectual and Developmental Disabilities), 31, 228-233.

Miller, E., \& Almon, J. (2009). Crisis in preschool: Why children need to play in school. College Park, MD: Alliance for Childhood.

Monahan, K. C., Oesterle, S., \& Hawkins, J. D. (2010). Predictors and consequences of school connectedness. The Prevention Researcher, 17(3), 3-6.

Morris, R. V. (2001). Drama and authentic assessment in a social studies classroom. Social Studies, 92(1), 41-45. http://dx.doi.org/10.1080/00377990109603974

Nichols, S., \& Stich, S. (2000). A cognitive theory of pretense. Cognition, 74, 115-147. http://dx.doi.org/10.1016/S0010-0277(99)00070-0

Olson, M. H., \& Hergenhahn, B. R. (2013). An introduction to theories of learning (9th ed.). Upper Saddle River, NJ: Pearson.

O'Neill, B. E. (2008). Storytelling and creative drama: A dynamic approach to inclusive early childhood education (Unpublished Doctoral dissertation). Columbia University, New York.

O’Neill, C., \& Lambert, A. (1991). Drama Structures: A practical handbook for teachers. U.S.A.: Heinemann Educational Books.

Özdemir, S. M., \& Çakmak, A. (2008). The effect of drama education on prospective teachers' creativity. International Journal of Instruction, 1(1), 13-30.

Pass, S. (2007). When constructivists jean Piaget and lev Vygotsky were pedagogical collaborators: A viewpoint from a study of their communications. Journal of Constructivist Psychology, 20, 277-282. http://dx.doi.org/10.1080/10720530701347944

Patrikakou, E. N. (2008). The power of parent involvement: Evidence, ideas, and tools for student success. Lincoln, IL: The Center on Innovation and Improvement. Retrieved from http://education.praguesummerschools.org/images/education/readings/2014/Patrikakou_Power_of_parent_i nvolvement.pdf

Patton, M. Q. (2002). Qualitative research \& evaluation methods (3rd ed.). Thousand Oaks, CA: Sage.

Philips, S. C. (2003). Drama with children. Oxford: Oxford University Press.

Punkoney, S. (2013). The benefits of dramatic play in early childhood education. Retrieved from http://stayathomeeducator.com/the-benefits-of-dramatic-play-in-early-childhood-education/

Rasmussen, B., \& Gürgens, R. (2006). Art as part of everyday life: Understanding applied theatre practices through the aesthetics of John Dewey and Hans Georg Gadamer. Theatre Research International, 31(3), 235-244. http://dx.doi.org/10.1017/S0307883306002203

Rosler, B. (2008). Process drama in one 5th grade Social Studies class. Social Studies, 99(6), 265-272. http://dx.doi.org/10.3200/TSSS.99.6.265-272

Sawyer, R. K. (2004). Creative teaching: Collaborative discussion as disciplined improvisation. Educational Researcher, 33(2), 12-20. http://dx.doi.org/10.3102/0013189X033002012

Selmanoğlu, E. (2009). The effect of creative drama on the achievement of the students of elementary school 5th grade Turkish course (Published Master's thesis). Abant İzzet Baysal University, Bolu, Turkey.

Sirisrimangkorn, L., \& Suwanthep, J. (2013). The effects of integrated drama-based role play and student teams achievement division (STAD) on students' speaking skills and affective involvement. Scenario, 2, 63-77.

Smith, S. M. (1984). The theatre arts and teaching of second languages. Reading. MA: Addison-Wesley.

Smith, P. K., \& Pellegrini, A. (2013). Learning through play. Encyclopedia on Early Childhood Development. Retrieved from http://www.childencyclopedia.com/documents/Smith-PellegriniANGxp2.pdf 
Staples, M. (2007). Supporting Whole-class collaborative inquiry in a secondary mathematics classroom. Cognition and Instruction, 25, 161-217. http://dx.doi.org/10.1080/07370000701301125

Şimşek, M. (2013). Yaratıcı drama dersinin sınıf öğretmeni adaylarının sosyal becerilerine etkisi [The effect of creative drama on preservice primary teachers' social skills] (Published Master's thesis). Ege University, İzmir, Turkey.

Tahta, F. (1999). Ĕgitimde drama nedir? Öğretmen yetiştirme lisans programinda yeri. Türkiye 1. Drama Liderleri Buluşması Bildirileri (pp. 92-94). Oluşum Tiyatrosu ve Drama Atölyesi, Ankara: Fersa Matbaacilik.

Taylor, P. (1998). Redcoats and patriots: Reflective practice in drama education and social studies. Portsmouth, NH: Heinemann.

Taylor, P., \& Warner, C. (2006). Structure and spontaneity: The process drama of Cecily O'Neill. UK: Trentham Books Limited.

Thomas, S. P., \& Smith, H. (2004). School connectedness, anger behaviors, and relationships of violent and nonviolent American youth. Perspectives in Psychiatric Care, 40(4), 135-147. http://dx.doi.org/10.1111/j.1744-6163.2004.tb00011.x

Thompson, D. R., Lachan, R., Overpeck, M., Ross, J. G., \& Gross, L. A. (2006). School connectedness in the health behavior in school-aged children study: The role of student, school, and school neighborhood $\begin{array}{lllll}\text { characteristics. Journal of School Health, } & \text { 76(7), }\end{array}$ http://dx.doi.org/10.1111/j.1746-1561.2006.00129.x

Ting, S. (2005). Drama-assisted high school English's listening and speaking instruction. Retrived from http://nccuir.lib.nccu.edu.tw/handle/140.119/31818

Treff, M. E. (2008). The essence of Participation Training: A phenomenological examination of graduate student experiences (Doctoral dissertation). Available on ProQuest Dissertations and Theses.

Tutty, L. M., Rothery, R. M., \& Grinnell, J. R. (1996). Analyzing your own data, qualitative research for social workers. Calgary, Canada: Allyn and Bacon.

Umar, Ç. N., \& Okka, A. (2012). Implementing creative drama and game based activities to attain permanent learning of the subject "nomenclature of compounds". New Perspectives in Science Education. Paper presented in Pixel International Conference, Florence, Italy.

Viera, A. J., \& Garrett, J. M. (2005). Understanding interobserver agreement: The kappa statistic. Family Medicine, 37(5), 360-363.

Viciana, J. (2013). Effect of internships on pre-service teachers' conceptions of planning in physical education. European Scientific Journal, 9(19), 253-261.

Wagner, B. J. (2002). Understanding drama-based education. London: Ablex Publishing.

Whitlock, J. L. (2006). Youth perceptions of school: Contextual correlates of school connectedness in adolescence. Applied Developmental Science, 10(1), 13-29. http://dx.doi.org/10.1207/s1532480xads1001_2

Yamamoto, R. H. (2015). Serious fun: The perceived influences of improvisational acting on community college students (Doctoral Dissertation). Walden University, Minneapolis, Minnesota, the USA.

Yıldırım, A., \& Şimşek, H. (2008). Nitel araştırma yöntemleri (7th ed.). Ankara: Seçkin Yayıncılık.

Yılmaz, G. (2006). Fen Bilgisi öğretiminde drama yönteminin kullanımı [Using method of drama in science education] (Published Master's thesis). Pamukkale University, Denizli, Turkey. 


\section{Appendix}

Table 6. Kappa values of the themes emerging from the views of the participants

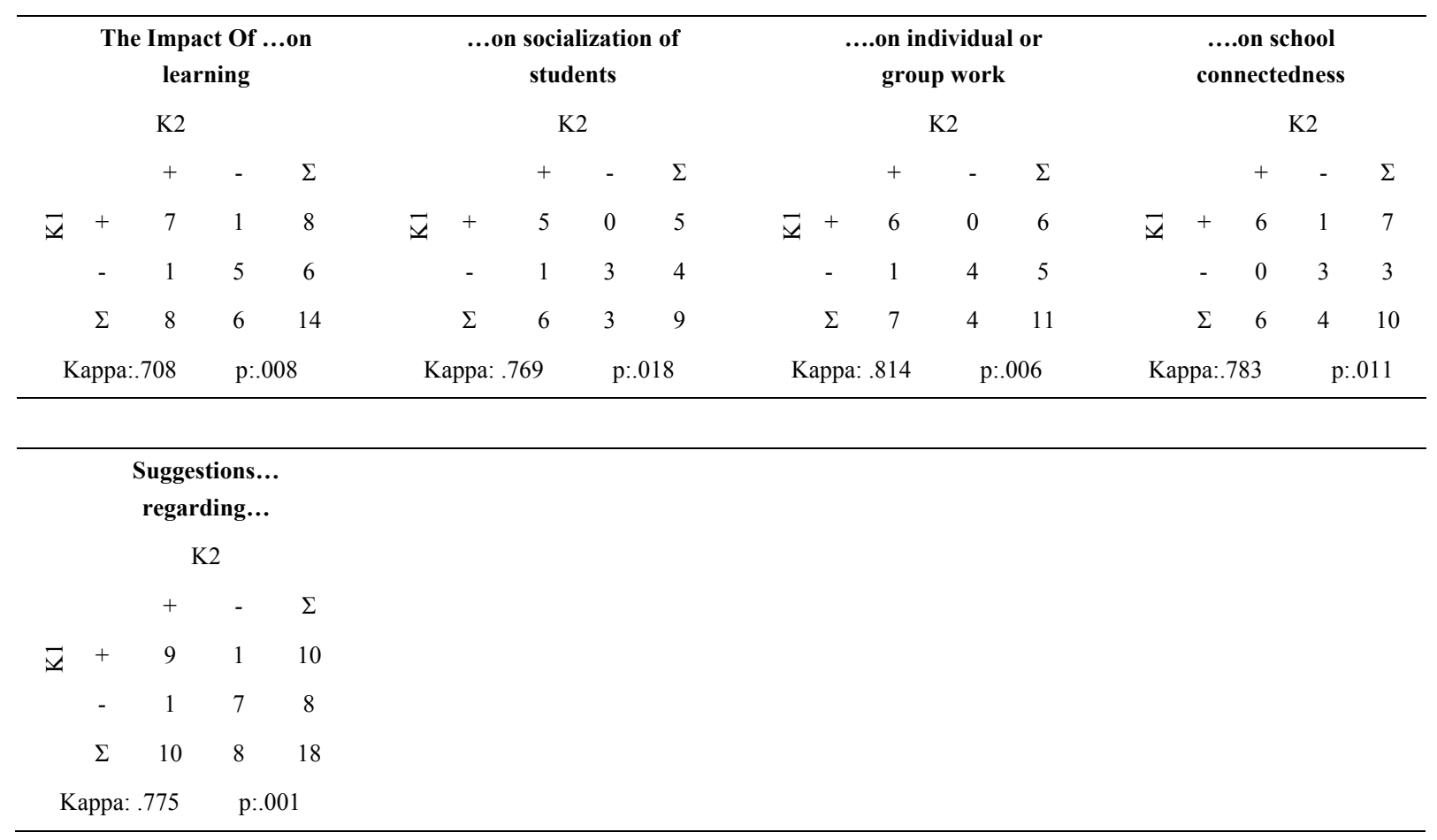

\section{Copyrights}

Copyright for this article is retained by the author(s), with first publication rights granted to the journal.

This is an open-access article distributed under the terms and conditions of the Creative Commons Attribution license (http://creativecommons.org/licenses/by/4.0/). 